\title{
Tourists satisfaction analysis of Sanya Dadonghai Tourist Attraction- Based on IPA Method
}

\author{
Danhe Wang ${ }^{1, a,{ }^{*}}$ \\ ${ }^{1}$ School of International Hospitality Management, Sanya University, \\ Sanya, 572022, China \\ a838117296@QQ.com \\ ${ }^{\star}$ Corresponding author
}

Keywords: tourist satisfaction, IPA analysis method, Sanya Dadonghai tourist attraction

\begin{abstract}
Tourist satisfaction, as a key factor affecting the competitiveness of tourist attractions, has important research significance. This paper takes the Dadonghai tourist attraction as the research object, analyzes the collected data by using IPA analysis method and obtains the four aspects of tourist satisfaction index data of design layout, environment and supporting facilities, personnel services and tourism products and catering of Dadonghai tourist attraction and give evaluation and improvement suggestions from these four aspects
\end{abstract}

\section{Introduction}

Sanya Dadonghai tourist attraction is located in Sanya City, the southernmost tropical coastal city in China and the tourist attraction is free to enter, after 8 years of development and construction, it has built the Pearl Square, the Seaside leisure lovers sightseeing Road, the bar corridor with exotic flavor and the coastal Seafood square, as well as the children's amusement park, the tourist commodity store, South coffee bar, beer house and other supporting facilities. It is one of the most popular tourist attractions. With the continuous growth of the number of tourists, strengthening the quality construction of the Dadonghai tourist attraction and improving the tourist satisfaction is a problem that the tourist attraction managers must consider.

The questionnaire is mainly divided into three parts, the first part is the basic information of tourists, including: gender, age, degree of education, occupation, monthly income and other issues; the second part is the consuming behavior of tourists, including: time selection for touring the Dadonghai tourist attraction, Information access of the Dadonghai tourist attraction, travelling form and where to come from and other issues. The third part is the evaluation of the importance and satisfaction of tourists to the Dadonghai tourist attraction and use Likert Five-Point Satisfaction Scale to consider the four aspects of the layout of the tourist attraction, the environment and supporting facilities, environment and supporting facilities, personnel services and tourism products and catering. Among them, "1" stands for "very unimportant / very dissatisfied ", "2" stands for "not important / unsatisfactory", "3" stands for "general", "4" stands for "important / relatively satisfactory", "5" stands for "very important / very satisfied". Through consulting the relevant literature on tourist satisfaction, this paper summarizes the Influencing Indicators of tourist satisfaction and determines the evaluation index of tourist satisfaction as follows:

Table 1 Design table of impact index for tourist satisfaction

\begin{tabular}{|l|l|}
\hline Product elements & Evaluating indicator \\
\hline Design layout of the scenic spot & Infrastructures layout \\
\cline { 2 - 2 } & Projects scenario design \\
\cline { 2 - 2 } & Architectural characteristic landscape design \\
\cline { 2 - 2 } & Theme positioning and design \\
\cline { 2 - 2 } & Tourist commodities design \\
\cline { 2 - 2 } & Design of performing arts festivals and other special events \\
\hline Environment and supporting facilities & Safety of facilities in the scenic spot \\
\cline { 2 - 2 } of the scenic spot & Rationality of recreational facilities in the scenic spot \\
\hline
\end{tabular}




\begin{tabular}{|l|l|}
\hline \multirow{5}{*}{ Personnel service of the scenic spot } & Convenience of internal traffic in the scenic spot \\
\cline { 2 - 2 } & Definition of direction signs in the scenic spot \\
\cline { 2 - 2 } & Rationality of toilet arrangement \\
\cline { 2 - 2 } & Queuing time for playing \\
\cline { 2 - 2 } & Environmental health degree of the scenic spot \\
\hline \multirow{5}{*}{ Tourism commodities and catering } & Service attitude of personnel \\
\cline { 2 - 2 } & Professionalism of personnel services \\
\cline { 2 - 2 } & Comprehensiveness of personnel services \\
\cline { 2 - 2 } & Timeliness of personnel services \\
\cline { 2 - 2 } & Personalized service of personnel \\
\hline & Diversity of range of characteristics \\
\cline { 2 - 2 } & Commodity characteristics \\
\cline { 2 - 2 } & Cost performance of commodities \\
\hline & Convenience of commodities \\
\cline { 2 - 3 } & Cost performance of catering \\
\cline { 2 - 3 } & Diversity of catering \\
\hline & Characteristics of catering \\
\cline { 2 - 3 } & Catering environment \\
\hline
\end{tabular}

A total of three spot field surveys were conducted to the Dadonghai tourist attraction in November 2017and December 2017, during the survey, 170 questionnaires were sent out with a simple random sampling method, a total of 157 copies except incomplete invalid questionnaires and the response rate is $92.35 \%$.

In order to make the questionnaire reliable, this paper analyzes the reliability of importance and satisfaction scale of products of the Dadonghai tourist attraction. SPSS20 for windows is used to test 26 questions and the $\alpha$ value of importance is 0.959 and the $\alpha$ value of satisfaction is 0.965 . Cronbachaerf alpha (reliability coefficient method) was more than 0.8 , which indicates that the reliability is high. This shows that the reliability of the questionnaire is strong. The analysis table is as follows

Table 2 Reliability statistics of tourist importance

\begin{tabular}{|l|l|l|}
\hline Cronbach's Alpha & $\begin{array}{l}\text { Cronbachs Alpha } \\
\text { Cronbachs Alpha based on standardized items }\end{array}$ & $\begin{array}{l}\text { Number of } \\
\text { terms }\end{array}$ \\
\hline .959 & .959 & 26 \\
\hline
\end{tabular}

Table 3 Reliability statistics of tourist satisfaction

\begin{tabular}{|l|l|l|}
\hline Cronbach's Alpha & $\begin{array}{l}\text { Cronbachs Alpha } \\
\text { Cronbachs Alpha based on standardized items }\end{array}$ & $\begin{array}{l}\text { Number of } \\
\text { terms }\end{array}$ \\
\hline .965 & .965 & 26 \\
\hline
\end{tabular}

The full name of IPA analysis method is Importance Performance Analysis, among them, I indicate importance and $\mathrm{P}$ indicate satisfaction and in order to objectively measure the difference between importance and satisfaction, construct the IPA index measure formula as:

$$
\text { IPAI=(I-P)/I*100 }
$$

In the formula, IPAI represents the importance performance analysis index. According to the formula, IPA index is negatively correlated with satisfaction. To reflect the impact of product indicators on satisfaction, the IPA index is divided into five levels. Index $\leq 5.00$ is very satisfactory; 5.01-10.00 is relatively satisfactory; $10.01-20.00$ is general; $20.01-30.00$ is unsatisfy; $\geq 30.01$ is very unsatisfactory.

\section{Evaluation and statistical analysis of design layout products of the scenic spot}


Table 4 Assessment distribution table of design layout products of the scenic spot

\begin{tabular}{|l|l|l|l|l|l|l|l|}
\hline Assessment element & \multicolumn{2}{|l|}{ Importance } & Satisfaction & & & \\
\hline & $\begin{array}{l}\text { Mean } \\
\text { value }\end{array}$ & $\begin{array}{l}\text { Standard } \\
\text { deviation }\end{array}$ & $\begin{array}{l}\text { Mean } \\
\text { value }\end{array}$ & $\begin{array}{l}\text { Standard } \\
\text { deviation }\end{array}$ & I-P & $\begin{array}{l}\text { IPA } \\
\text { index }\end{array}$ & Sort \\
\hline Infrastructure layout & 4.02 & 0.90 & 3.78 & 0.72 & 0.24 & 5.97 & 1 \\
\hline Projects scenario design & 4.08 & 0.73 & 3.71 & 0.69 & 0.37 & 9.07 & 5 \\
\hline $\begin{array}{l}\text { Architectural characteristic landscape } \\
\text { design }\end{array}$ & 4.04 & 0.81 & 3.78 & 0.69 & 0.26 & 6.44 & 2 \\
\hline Theme positioning and design & 4.24 & 0.74 & 3.73 & 0.73 & 0.51 & 12.03 & 6 \\
\hline Tourist commodities design & 3.79 & 0.94 & 3.48 & 0.76 & 0.31 & 8.12 & 3 \\
\hline $\begin{array}{l}\text { Design of performing arts festivals } \\
\text { and other special events }\end{array}$ & 3.95 & 0.88 & 3.62 & 0.79 & 0.33 & 8.35 & 4 \\
\hline
\end{tabular}

According to the table, the analysis of the survey results of 157 tourists shows that the tourists' importance evaluation mean value of the six project elements of the design layout of the Dadonghai scenic spot is arranged from high to low: theme positioning and design, project scenario design, architectural characteristic landscape design, infrastructure layout, Performance Festival and other special activities, design of tourist commodities. In addition to tourism commodities design and Performance Festival design, the importance mean value of other elements are more than 4.00, which shows that tourists have high expectations for the design layout of the various elements of the scenic spot. Tourists satisfaction evaluation of the six elements of the layout of the scenic area is from high to low: tourist commodities design, performance festivals and other special activities design, project scenarios design, theme positioning and design, infrastructure layout and architectural landscape design. None of the six elements exceeded 4.00, indicating that tourists were not very satisfied with the layout of the scenic spot. According to the IPA index of six projects, apart from theme positioning and design, the other projects are more satisfactory.

\section{Evaluation and statistical analysis of Environment and supporting facilities products of the scenic spot}

Table 5 Assessment distribution table of environment and supporting facilities products of the scenic spot

\begin{tabular}{|l|l|l|l|l|l|l|l|}
\hline Assessment element & \multicolumn{2}{|l|}{ Importance } & \multicolumn{2}{|l|}{ Satisfaction } & \multicolumn{3}{l|}{} \\
\hline & $\begin{array}{l}\text { Mean } \\
\text { value }\end{array}$ & $\begin{array}{l}\text { Standard } \\
\text { deviatio } \\
\mathrm{n}\end{array}$ & $\begin{array}{l}\text { Mean } \\
\text { value }\end{array}$ & $\begin{array}{l}\text { Standard } \\
\text { deviation }\end{array}$ & I-P & $\begin{array}{l}\text { IPA } \\
\text { index }\end{array}$ & Sort \\
\hline Safety of facilities in the scenic spot & 4.59 & 0.71 & 4.05 & 0.78 & 0.54 & 11.76 & 2 \\
\hline $\begin{array}{l}\text { Rationality of recreational facilities in } \\
\text { the scenic spot }\end{array}$ & 4.29 & 0.80 & 3.80 & 0.75 & 0.49 & 11.42 & 1 \\
\hline $\begin{array}{l}\text { Convenience of internal traffic in the } \\
\text { scenic spot }\end{array}$ & 4.39 & 0.70 & 3.68 & 0.80 & 0.71 & 16.17 & 4 \\
\hline $\begin{array}{l}\text { Clarity of direction signs in the scenic } \\
\text { spot }\end{array}$ & 4.42 & 0.73 & 3.73 & 0.78 & 0.69 & 15.61 & 3 \\
\hline $\begin{array}{l}\text { Rationality of toilet location } \\
\text { arrangement }\end{array}$ & 4.30 & 0.75 & 3.57 & 0.83 & 0.73 & 16.98 & 5 \\
\hline Queuing time for play projects & 4.38 & 0.74 & 3.08 & 0.92 & 1.30 & 29.68 & 7 \\
\hline Health conditions of scenic environment & 4.47 & 0.71 & 3.60 & 0.93 & 0.87 & 19.46 & 6 \\
\hline
\end{tabular}

The table shows that tourists think that the environment and supporting facilities of the scenic spot are very important and can reach more than 4.00 , which indicate that tourists are very concerned about the environment and supporting facilities of scenic spot. From the tourist satisfaction can be seen that tourists are very satisfied with the safety of scenic facilities, tourists are generally satisfied or satisfied with the other projects. According to the IPA index, tourists are not satisfied with the queuing time of the game projects and the IPA index reaches 29.68. The IPA index of other projects is over 10.00 and below 20.00, indicating that tourists are generally satisfied with these projects. 


\section{Evaluation and statistical analysis of personnel service of the scenic spot}

Table 6 Assessment distribution table of personnel service of the scenic spot

\begin{tabular}{|l|l|l|l|l|l|l|l|}
\hline Assessment element & Importance & \multicolumn{2}{|l|}{ Satisfaction } & \multicolumn{2}{l|}{} \\
\hline & $\begin{array}{l}\text { Mean } \\
\text { value }\end{array}$ & $\begin{array}{l}\text { Standard } \\
\text { deviation }\end{array}$ & $\begin{array}{l}\text { Mean } \\
\text { value }\end{array}$ & $\begin{array}{l}\text { Standard } \\
\text { deviation }\end{array}$ & I-P & $\begin{array}{l}\text { IPA } \\
\text { index }\end{array}$ & $\begin{array}{l}\text { Sort } \\
\text { Service attitude of personnel }\end{array}$ \\
\hline Professionalism of personnel services & 4.31 & 0.83 & 3.70 & 0.83 & 0.61 & 14.15 & 4 \\
\hline Comprehensiveness of personnel services & 4.06 & 0.85 & 3.69 & 0.82 & 0.60 & 13.99 & 3 \\
\hline Timeliness of personnel services & 4.34 & 0.69 & 3.53 & 0.81 & 0.81 & 18.66 & 5 \\
\hline Personalized service of personnel & 3.97 & 0.96 & 3.46 & 0.90 & 0.51 & 12.95 & 1 \\
\hline
\end{tabular}

It can be seen from the table that among the 157 tourists randomly surveyed, the importance of personalized service of personnel is relatively high, indicating that tourists' requirements for personalized service of personnel of the scenic spot are very important. Tourists' satisfaction on the five elements of the personnel service is between 3.00 and 4.00, which is between somewhat satisfied and satisfied. According to the IPA index, we can see that Tourists' satisfaction on the five elements of the personnel service is between 10.00 and 20.00, which indicate that tourists are generally satisfied with the Personnel service of the scenic spot, which needs to be upgraded and improved

\section{Evaluation and statistical analysis of tourist commodities and catering}

Table 7 Assessment distribution table of tourist commodities and catering

\begin{tabular}{|l|l|l|l|l|l|l|l|}
\hline Assessment element & \multicolumn{2}{|l|}{ Importance } & \multicolumn{3}{l|}{ Satisfaction } & \multicolumn{3}{l|}{ Sort } \\
& $\begin{array}{l}\text { Mean } \\
\text { value }\end{array}$ & $\begin{array}{l}\text { Standard } \\
\text { deviation }\end{array}$ & $\begin{array}{l}\text { Mean } \\
\text { value }\end{array}$ & $\begin{array}{l}\text { Standard } \\
\text { deviation }\end{array}$ & I-P & IPA \\
\hline Diversity of commodities & 4.06 & 0.86 & 3.67 & 0.80 & 0.39 & 9.61 & 2 \\
\hline Commodity characteristics & 4.03 & 0.83 & 3.65 & 0.80 & 0.38 & 9.43 & 1 \\
\hline Cost performance of commodities & 4.22 & 0.84 & 3.50 & 0.93 & 0.72 & 17.06 & 8 \\
\hline Portability of commodities & 4.03 & 0.78 & 3.49 & 0.90 & 0.54 & 13.40 & 6 \\
\hline Cost performance of catering & 4.18 & 0.80 & 3.49 & 0.92 & 0.69 & 16.51 & 7 \\
\hline Diversity of catering & 4.05 & 0.80 & 3.59 & 0.83 & 0.46 & 11.36 & 3 \\
\hline Characteristics of catering & 4.05 & 0.81 & 3.52 & 0.90 & 0.53 & 13.09 & 4 \\
\hline Catering environment & 4.34 & 0.78 & 3.77 & 0.80 & 0.57 & 13.13 & 5 \\
\hline
\end{tabular}

From the table, tourists think that the index of tourism commodities and catering is very important, up to 4.00 or more, it can be said that tourists pay more attention to the catering food and environment of Sanya Dadonghai tourist attraction. According to the IPA index value, tourists are satisfied with the diversity of commodities and the characteristics of commodities in the Dadonghai tourist attraction, the IPA index value is between 5.00 and 10.00. IPA index value of the other six project elements is between 10.00-20.00, which is somewhat satisfied. In the course of the survey, many tourists buy goods mostly for their relatives and friends as a memorial. In tourism commodities and catering, catering environment is the most important one for tourists, the feedback from tourists is generally satisfactory, which shows this should be improved.

\section{IPA results and analysis of tourist satisfaction}




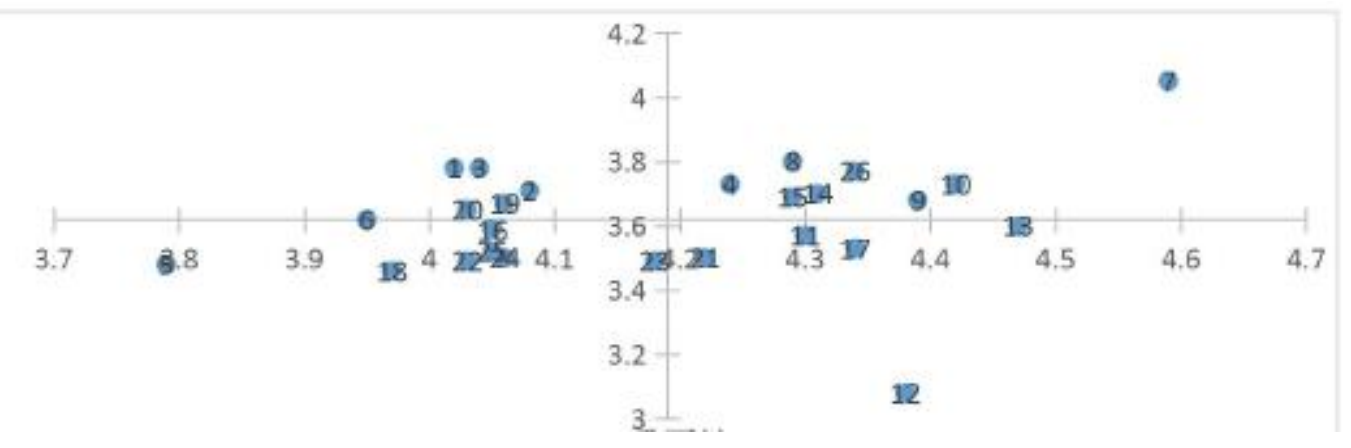

Figure 4.9 Importance Performance of Tourist satisfaction of Sanya Dadonghai tourist attraction IPA model ( 1 Infrastructure layout 2 Project scenario design 3 Architectural characteristic landscape design 4 Theme positioning and design 5 Design of tourist commodities 6Design of performing arts festivals and other special events 7 Safety of facilities in scenic spot 8 Rationality of recreational facilities in the scenic spot 9 Convenience of internal traffic in the scenic spot 10 Clarity of direction signs in the scenic spot 11 Rationality of toilet location arrangement 12 Queuing time for playing projects 13 Hygienic condition of the scenic spot 14 Service attitude of personnel 15 Professionalism of personnel services 16 Comprehensiveness of personnel services 17 Timeliness of personnel services 18 ersonalized service of personnel 19Diversity of commodities 20 Commodity characteristics 21 Cost performance of commodities 22 Convenience of commodities 23 Cost performance of catering 24 Diversity of catering25 Characteristics of catering 26 Catering environment)

\subsection{First quadrant(predominance area)}

From the graph, we can see that in this quadrant area, all the indicators are higher than the mean value of importance and satisfaction, belonging to high importance and high satisfaction indicators. This quadrant includes eight indicators: theme positioning and design, Safety of facilities in the scenic spot, rationality of recreational facilities in the scenic spot, Convenience of internal traffic in the scenic spot, Clarity of direction signs in the scenic spot, Service attitude of personnel, professionalism of personnel service and catering environment in the predominance area. According to the principle of IPA analysis, it can be explained that tourists are satisfied with the eight indicators of Sanya Dadonghai tourist attraction and the performance is good.

\subsection{Second quadrant(holding area)}

The index in the quadrant area is high satisfaction and low importance, including five indicators: infrastructure layout, project scenario design, architectural characteristic landscape design, diversity of commodities and commodity characteristics. According to the IPA index, these five indicators are all between 5.01and10.00 and are relatively satisfactory. According to the principle of IPA analysis, the index in the holding area is relatively unimportant and judging from the satisfaction value above the importance value, the evaluation exceeded expectations. Therefore, these are the positive factors of tourists satisfaction in Dadonghai scenic spot of Sanya and need to be maintained.

\subsection{Third quadrant(modified area)}

The index in the quadrant area is low importance and low satisfaction, including seven indicators, such as tourism commodity design, the comprehensiveness of personnel services, personalized service of personnel, Portability of commodity, Cost performance of catering, diversity of catering and catering characteristics. Among them, the IPA index of tourism commodity design is 8.12, between 5.01 and 10.00, is satisfactory and the other six indexes are between 10.01 and 20.00, which is generally satisfactory. In this case, because the design of tourist commodities is a part of the Design layout of scenic spot, most of the visitors are not important to the architectural design, or even pay little attention to it. For the diversity and characteristics of catering in the Dadonghai scenic spot, tourists feel unimportant during the survey because the restaurants in each scenic spot are 
limited and tourists do not expect much. However, the prices of catering products in scenic spots are generally high. If the Dadonghai scenic spot is improved in these aspects, it will bring different benefits to the scenic spot.

\subsection{Fourth Quadrant(weak area)}

The index in this area is high importance and low satisfaction, which includes five indexes, such as the rationality of toilet location arrangement, queuing time for playing items, environmental health status of the scenic spot, timeliness of personnel services and cost performance of commodities. Among them, the IPA index of queuing time for playing projects is 29.68 , which is between 20.01 and 30.00, is unsatisfy. The IPA index of other indicators is 10.01-20.00, which is generally satisfactory. Most tourists think that environmental hygiene is very important and no tourists are willing to play in places with poor environmental hygiene. In the course of the survey, the existing tourists unconsciously throw their garbage on the ground and this kind of uncivilized behavior affects the tourist satisfaction.

\section{References}

[1] Metin Kozak, Repeaters' behaviorat two distinct destinations[J]. Annals of Tourism Research, $\mathrm{v}$ ol.28,pp.708-804,2001.

[2] Ignacio A.Jesus Collado, The role of expectations in the consumer satisfaction formation proces s:Empirical evidence in the travel agency sector [J]. Tourism Management,vol.,27,pp.410-419.2 006.

[3] Teresa Ince,David Bowen. Consumer satisfaction and services:insights from dive tourism[J]. T heService Industries Journal,vol.31,pp.1769-1792,2011. 